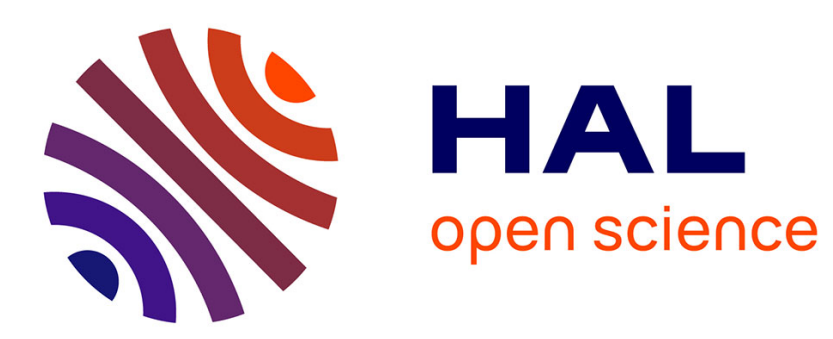

\title{
Archaic and innovative Islamic prayer names around the Sahara \\ Lameen Souag
}

\section{To cite this version:}

Lameen Souag. Archaic and innovative Islamic prayer names around the Sahara. Bulletin of the School of Oriental and African Studies, 2015, 78 (2), pp.357-374. 10.1017/S0041977X15000075 . halshs-01376184

\section{HAL Id: halshs-01376184 \\ https://shs.hal.science/halshs-01376184}

Submitted on 4 Oct 2016

HAL is a multi-disciplinary open access archive for the deposit and dissemination of scientific research documents, whether they are published or not. The documents may come from teaching and research institutions in France or abroad, or from public or private research centers.
L'archive ouverte pluridisciplinaire HAL, est destinée au dépôt et à la diffusion de documents scientifiques de niveau recherche, publiés ou non, émanant des établissements d'enseignement et de recherche français ou étrangers, des laboratoires publics ou privés. 


\title{
Archaic and innovative Islamic prayer names around the Sahara
}

\author{
Lameen Souag, LACITO (CNRS / Université Paris III / INALCO) - lameen@ gmail.com
}

[Postprint version of: Bulletin of the School of Oriental and African Studies 78:2, pp. 357374, 2015. DOI: 10.1017/S0041977X15000075.]

\begin{abstract}
:
Berber in the Sahara and southern Morocco, and several West African languages including Soninké, Mandinka, and Songhay, all refer to the five Islamic daily prayers using terms not derived from their usual Arabic names, and showing striking mutual similarities. These names' motivation has not hitherto been explained. An examination of Islamic sources reveals that many correspond to terms attested within Arabic from an early period which have passed out of use elsewhere. Others, with a more limited distribution, reflect transfer from a time-keeping system widely attested among Berber-speaking oases of the northern Sahara. These results demonstrate that the variant prayer terminologies attested in the hadith reflect popular usages that were still commonplace at the time when North Africa was conquered, and underscore the conservatism of non-Arabic Islamic religious terminology in and around the Sahara.
\end{abstract}

Keywords: Arabic, Berber, Sahel, etymology, prayer, early Islam

\section{Introduction}

North Africa occupies a special position in the history of Islam, as the first region to be separated politically from the caliphate while maintaining the religion. By the early Abbasid period, the coast had passed out of effective Abbasid control, while the fringes of the Sahara were dominated by Ibādī and Șufrī states which rejected not only the rule of the Abbasids but also their Sunnī orthodoxy, and were hence rather reserved in their attitude towards the works of the most influential religious scholars of the Abbasid era. This position is reflected in the religious terminology of the non-Arabic languages of the region, which preserve reflexes of variant forms attested in early Islamic traditions but obsolete in most other parts of the Islamic world. ${ }^{1}$

A significant number of Berber languages, along with some of their neighbours, refer to the five daily prayers of Islam using words that cannot be derived from their usual Arabic names; most of these are internal formations, briefly discussed by Naït-Zerrad (1998), while others are Arabic loans. Van den Boogert and Kossmann (1997) give Berber-internal etymologies for these forms, and argue that their consistent use by both Sunnī and Ibādī groups indicates that they must have been produced by a single centre of Islamisation, probably Ibādīi, at a period before the Sunnī-Ibādī split became a significant factor in the region, ie no later than the Umayyad era. Comparable forms which have attracted less comment are also found in a number of west African languages - notably Soninké and

1 Most, but not all; shortly after this article was accepted for publication, François de Blois (p.c.) pointed out that some of the names discussed here have close Persian parallels, which must be taken into account in future work 
Songhay, the languages of the first major Sahelian states to come into direct contact with Islam, as well as their neighbours to the south, such as Mandinka and Pular. This paper's appendix tabulates all available prayer names in languages for which data was available, along with references.

In this paper, I will show that some of these unexpected forms can be traced directly back to variants attested in the early hadith literature, via borrowing or calquing. While modern Islamic literature consistently refers to the prayers by the names Fajr / Subh (in the morning), $Đ u h r^{2}$ (at noon), 'Așr (in the afternoon), Maghrib (at sunset), and 'Ishā' (at nightfall), mainly derived from terms referring to the time of day, authoritative earlier sources including Șaḥị al-Bukhārī attest to the existence and wide usage within Arabic of alternative names for several of these prayers, as noted briefly in Wensinck (1987). These names have long since disappeared from Arabic usage, but reflexes of them continue to be used across much of North and West Africa. Their ubiquity throughout the Sahara constitutes compelling evidence that the first Arabs to introduce Islam to the region habitually used these alternative terms in their speech, and not the ones that have become usual. In this particular instance, seemingly non-standard traditions of Islam in the Sahara do not reflect local innovation, but rather provide information on the distribution of variation that was accepted within early Islam and only later came to be levelled out.

Other Berber forms that are almost as widespread, however, cannot be derived from Arabic through calquing or otherwise: they are rather derivations based on Berber numerals, with 'Așr = four, Maghrib = five, and 'Ishā' $=$ six. The reasons for the choice of these numbers have not been convincingly explained. I will argue below that these forms reflect a system of time-keeping widespread among Saharan oases, and still used within living memory. The wide usage of these forms suggests that this time-keeping system too dates back at least to the Umayyad period.

\section{Early prayer names in Arabic}

An obvious starting point for the early variation in prayer names is the hadith literature: convenient sources include Mālik (d. 795), 'Abd al-Razzāq (d. 826), al-Bukhārī (d. 870), and Muslim (d. 875). For the most part, these all use the familiar names mentioned above; however, they also faithfully record variants that do not correspond to the preferred terminology. Of several hadith reflecting these variations, the following (Bukhārī \#547 (2001:114)) is particularly revealing:

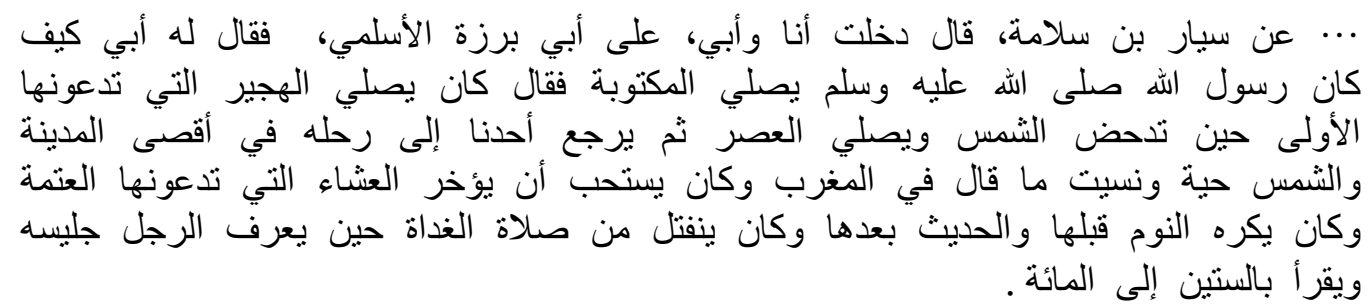

2 The transcription followed in this paper for both Arabic and non-Arabic data uses the following digraphs: sh for $\left[\int\right]$, th for $[\theta]$, dh for $[ð]$, kh for $[\mathrm{x}] /[\chi]$, gh for $[в]$. This transcription follows this journal's usual

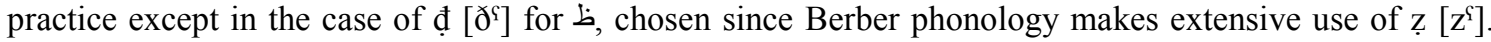
The author thanks anonymous reviewers and Maarten Kossmann for helpful comments on earlier drafts. 
"... from Sayyār b. Salama: "My father and I entered into the presence of Abū Barza al-'Aslamī. My father asked him: "How did the Messenger of God, blessings and peace be upon him, pray the prescribed (prayers)?" He replied: "He used to pray al-hajī $r$, which you (pl.) call al-'ūla, when the sun declines (from the meridian), and pray al- "așr such that one of us could return to his home at the far end of Medina while the sun was still lively." I forget what he said about al-maghrib. "And he used to prefer to delay al- 'ishā', which you (pl.) call al-'atama, and he used to hate sleeping before it or speaking after it. And he used to return from the ghadāt prayer when a person could recognise the one sitting next to him, and read sixty to a hundred ('āyät.)"'”

The people in this conversation were most likely living in Basra in the early $8^{\text {th }}$ century, but this hadith presents them not only as not using the set of prayer names familiar to modern Arabic speakers, but as each using a slightly different set of names. The familiarity of Abu Barza with the set he attributes to "you (pl.)", however, suggests that the latter rather than the former was prevalent in contemporary Basra. By implication, the terms for which he does not give an alternative were presumably common to both groups.

A similar usage combining features of both sets - possibly with reference to the times rather than to the associated prayers - is attributed to the Prophet himself in Mālik 3.3 $(1985: 78)=$ Bukhārī \#652 (2001:132):

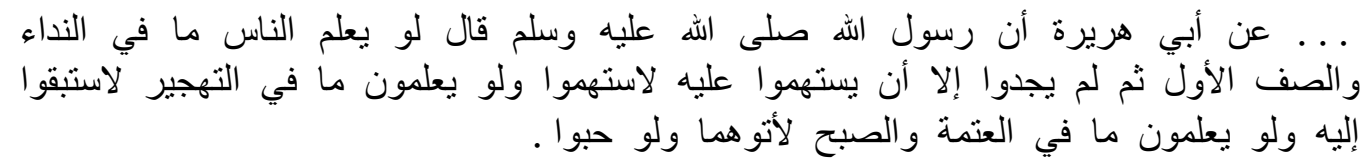

... from Abū Hurayra, that the Messenger of God, blessings and peace be upon him, said: "If people knew what is in the call and the first row, and found no (alternative) but to draw lots for it, they would draw lots. If they knew what is in al-tahjīr they would race each other to it. If they knew what was in al"atama and al-subh, they would come to it even crawling."

Outside the hadith literature, the book Al-Kämil by al-Mubarrad (d. 898), from Basra, mentions all three of the relevant terms, in a discussion of genitive constructions (Mubarrad 1864:128):

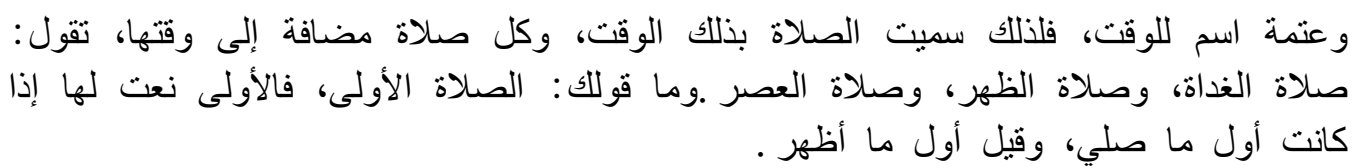

And 'atama is the name of a time, and the prayer at that time was named after it; every prayer is mudâa (annexed) to its time, so you say: șalāt al-ghadāt, șalāt

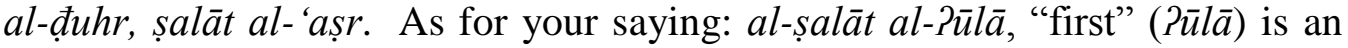
adjective modifying it, it being the first to have been prayed, and some say the first to be made known. 
A practically isolated term nevertheless attested quite early is salāt al-nawm, reported in 'Abd al-Razzāq \#2136 (Șan'ān̄i 1970:562):

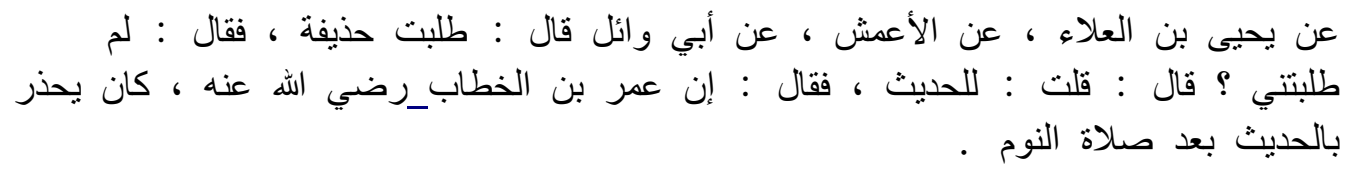

"From Yahyā b. al-'Alā', from al-A'mash, from Abū Wā'il who said: I asked for Hudayfa, and he said: Why have you asked for me? I said: For conversation. He said: "UUmar b. al-Khatțāb, may God be pleased with him, used to warn against conversation after șalät al-nawm."

A further dimension of variation applies to the meaning of $a l$ - 'isha' '. Some speakers used this term to refer, not to 'Ishā', but to Maghrib - a usage condemned as a Bedouin solecism in the following hadith, Bukhārī \#563 (2001:117):

$$
\begin{aligned}
& \text { حدثنا أبو معمر - هو عبد الله بن عمرو ـ قال حدثنا عبد الوارث، عن الحسين، قال حدثنا }
\end{aligned}
$$

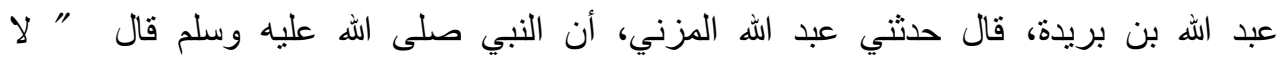

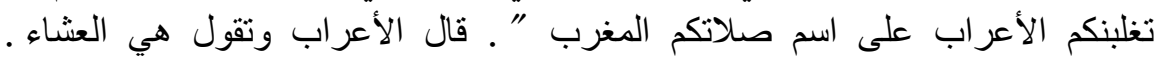

... 'Abd Allāh al-Māzinī told us that the Prophet, blessings and peace be upon him, said: "Do not let the Bedouin prevail over you in the name of your prayer al-maghrib." He said the Bedouin, and they call it al- 'ishā'.

This confusion might be avoided by referring to 'Ishā' as al- 'ishā'al-'äkhira, as in Muslim 465c (2006:215):

$$
\begin{aligned}
& \text { و . . . عن جابر بن عبد الله، أن معاذ بن جبل، كان يصلي مع رسول الله صلى الله عليه }
\end{aligned}
$$

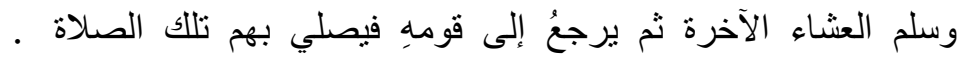

... from Jābir b. 'Abd Allāh that Mu'ādh b. Jabal would pray al- ishā' al'äkhira with the Messenger of God, peace and blessings be upon him, then go back to his people and lead them in that prayer.

We can conclude that at least the following variants were current in Arabic in the Umayyad era:

\begin{tabular}{|c|c|c|c|}
\hline & "Standard" & "Basran" & Other \\
\hline Șubh & al-ṣubh & al-ghadāt & \\
\hline Đ̣uhr & al-ạuhr & $a l-' \bar{u} l \bar{a}$ & al-hajīr, al-tahjīr \\
\hline 'Așr & al-'așr & & \\
\hline Maghrib & al-maghrib & & al- 'ishā' \\
\hline 'Ishā’' & al- 'ishā' & al-'atama & al-'ishā' al-'ākhira, al-nawm \\
\hline
\end{tabular}

Table 1: Variant prayer names in Arabic. 
A study of narrators might indicate whether these variants can be associated with particular regions or tribes, but that would take us beyond the scope of this paper. However, the same sources that indicate these variants also help explain their disappearance. The emergence of these hadith compilations reflects a wider move to codify the religion in writing, which in itself gave the preferred variants cross-regional prestige; on top of this, the main variant names of Maghrib and 'Ishā' were explicitly condemned as improper in several hadith. The example above is considered șahīh, as is what looks rather like a variant of it in Muslim \#644a:

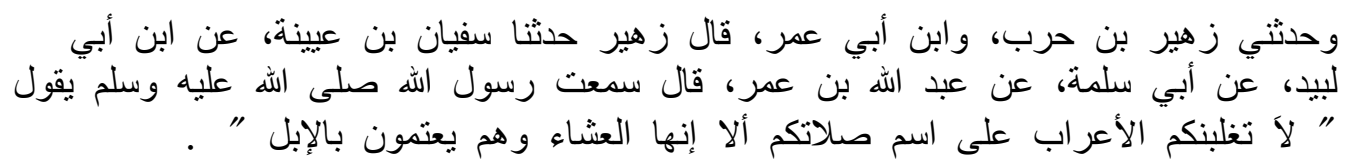

[...] From 'Abd Allāh b. 'Umar, who said: I heard the Messenger of God, blessings and peace be upon him, say: "Let the Bedouin not prevail over you in the name of your prayer, for it is al- 'isha';'; (they call it 'atama because) they stay late ('tm) with their camels."

But some less well-supported hadith object in much more extreme terms, such as Ibn 'Abī Shayba \#36971 (2006:537), narrating from the same source:

$$
\begin{aligned}
& \text { حدثنا وكيع قال ثنا شريك عن أبي فزارة العبسي عن ميمون بن مهرانَ قال قلت لعبد الله بن }
\end{aligned}
$$

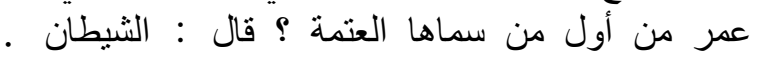

... from Maymūn b. Mihrān, who said: I asked 'Abd Allāh b. 'Umar "Who first called it al-"atama?" He replied: "The Devil!"

The end result, observable today, is that Muslims' prayer terminology is broadly uniform, in the Maghreb as elsewhere, and the variant oral traditions to which these hadith attest are known only to scholars. However, at the time of these compilations, most of North Africa was outside of Abbasid control, and much of it, particularly the northern Sahara, was nonSunnī. Mālikī Sunnism, though already present locally, would not begin to attain its current overwhelming preponderance until centuries later. This left ample time for the prayer names based on alternative oral traditions to become fixed in the region's languages, and the evidence below suggests that this is precisely what happened.

\section{Variants in the Western Islamic world}

\subsection{Salät al-’’̄lä (Đuhr)}

The term literally means "the first (f.)", 'ūla being the feminine form of 'awwal. A rather later authority, the Andalusian scholar al-Qurțubī (d. 1273), offers an explanation for the name in his commentary on Koran 12:109 (2006:411):

$$
\begin{aligned}
& \text { ومن قال صلاة الأولى فمعناه: عند صلاة الفريضة الأولى؛ وإنما سميت الأولى لأنها أول ما }
\end{aligned}
$$

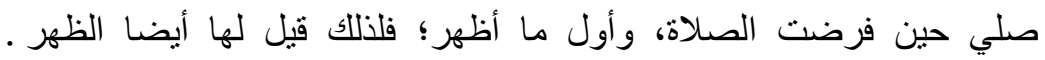


"Whoever says șalāt al-Pर्ulā, its meaning is "the first among the obligatory prayers", called "first" because it was the first prayer to be prayed when prayer was made obligatory, and the first to appear; that is why it is also called alđuhr."

At an early period, this name must have been rather widespread in the western half of the Islamic world; the only part of North Africa where it is consistently absent is the Mediterranean coast and its mountains. Even within Arabic, some Moroccan varieties still use luwli (Harrell \& Sobelman 2004:73). As a loan, it survives in scattered points stretching from southern Syria to the Niger bend: Western Neo-Aramaic 'alüla "Mittag" (Arnold 1990:333); in two eastern Berber languages - Sīwa luli "Đ̣uhr" (western Egypt), Awjila alûli "Đuhr" (eastern Libya); and in Songhay aluula "Đuhr" (eastern Mali, western Niger). (See Appendix for sources and tables.) The $i$ in the Berber forms reflects final imāla, echoed in Arabic dialects of the Egyptian oases (Woidich \& Behnstedt 1982:49).

As a calque, it survives in an area even larger and even more distant from the Middle Eastern heartland of early Islam. Within Berber, the commonest form for "Đuhr", excluding loanwords, is one reconstructible as ti-zwar-(nin), a feminine plural derived from the Berber root $\sqrt{ }_{z w r}$ "be first, precede" (Tashelhiyt zwur, Zenaga äžbər, Tamasheq ăzzar). The post-consonantal $w$ regularly corresponds to $b$ in Zenaga, while many varieties replace $z w$ with $z z$. Such forms are used to mean "Đuhr" across an enormous area including Tashelhiyt and Tamazight in southern Morocco; the Zenati Berber-speaking oases stretching across the northern Algerian Sahara, including the Gūrāra and Mzāā; Northwestern Libya, including the Nafūsa mountains and Zuwāra; Tuareg in the central Sahara; and Zenaga in Mauritania. Wolof (Senegal) and Korandjé (Algeria) have borrowed the Zenaga form: tisbar, tozborronn respectively.

The relevant Berber root has both the senses of "be first" and "precede", and Naït-Zerrad (1998:63) rendered these forms with the latter sense, as "celles qui précèdent", suggesting tentatively that it was so named because it was followed by additional recitations, as Lanfry noted for Ghadames. However, the Arabic loans exemplified above indicate that the relevant sense is not "precede", but rather "be first".

Soninké, the language of the early Sahelian state of Ghāna, has calqued rather than borrowed the term, whether directly from Arabic or from Berber, yielding sálli-fànà "prayer-first". This term has in turn been borrowed into West African languages to its south, such as Mandinka and Pular. In Bambara, it has been reinterpreted as based on fàná "meal" (Bailleul 1981), but the order indicates that this is a folk etymology, since the Bambara possessive construction is head-final.

\section{2. *Ṣalät al-Fịtr (Maghrib)}

Unlike the other terms discussed here, this term, literally "prayer of fast-breaking" (fitr being a deverbal noun from fatar " "break apart; break (fast)"), appears to be non-classical in the appropriate sense; the normal sense of the phrase is "(congregational) prayer on "Id al-Fitr (the fast-breaking festival after Ramadan)". The semantic shift is natural, given that in Ramadan one breaks one's fast each day at the time of Maghrib. No Arabic attestations 
of this usage have so far been found. However, their existence is implied by a series of West African terms for Maghrib which appear to be direct loans: Soninké fùtúrò, Mandinka fitiri, Timbuktu Songhay fitirow / futurow, etc. The vowels of the Soninké form suggest a possible alternative derivation from another form of the same root, futūr "breakfast, fastbreaking meal"; however, the absence of a long vowel and the other West African forms make this less probable.

This form was calqued into Berber at an early period, yielding ti-n-wučč $i$ "that (f.) of eating". It survives mainly in the westernmost Berber varieties - Tashelhiyt, Tamazight in southern Morocco, and Zenaga in Mauritania - but also in Zuwāra in northwestern Libya. It was loaned into Korandjé (Algeria) as tsyunzs; the Wolof form timis may also derive from this, assuming assimilation $* n w>m$.

This form is not attested in Tuareg, which consistently uses almoz "twilight", presumably a not very literal translation of maghrib based on a pre-existing time period. The predominant Zenati forms will be discussed below.

\subsection{Salāt al-'Ishā̄' ('Ishā'/ Maghrib)}

In the sense of 'Ishā', this form is dominant throughout modern Arabic, so its presence as a loan hardly merits comment. However, it is also present in one case as a calque within Berber: Nafusi $t i-n$-monsi "that (f.) of supper". Since the homonymy of reflexes of "ish $\bar{a}$ " ("evening", from the root Sashiy "be night-blind") and 'ash $\bar{a}$ ' is historically secondary, resulting from the weakening or loss of short vowels, this is probably a late development; comparison to Medieval Eastern Berber, which used ti-n-idas like most other Saharan Berber varieties (see below), would appear to confirm this.

A potentially more interesting calque based on this word is provided by Awjila mnishiw "p. del tramonto", to be derived by metathesis from *n-mishiw, cp. n "of", amishiw "cena [supper]". Available data on this form is ambiguous; Mauri (2011, ms) indicates that this refers to 'Ishā', but Paradisi's gloss rather suggests Maghrib. If the latter is correct, this usage would seem to reflect the confusing dialectal practice, mentioned and specifically condemned in Bukhārī, of calling Maghrib al- 'ishā'.

\section{4. Șalāt al-'Atama ('Ishā')}

Several hadith suggest that, in principle, the difference in name here corresponds with a difference in timing: al- "atama ("first third of the night", from the same root as 'atam "be late, become dark") refers to the late end of the time in which 'Ishā' should be prayed, whereas $a l$ - 'ish $\bar{a}$ ' refers to the early end. This form is rather less widely attested in North Africa than those seen so far, and no obvious calques are attested, but it occurs as a loan at opposite ends of the region. Alongside luli < al-'ūla for Đ̣uhr, it is still used in Siwi for 'Ishā': l'atmat. This is likewise the source for Morisco Spanish alatamo. However, reflexes of both al- 'isha' and al-'atama were adopted by the Church for translating canonical hours, confirming that the original semantic distinction between the two times was preserved in at least some registers of Andalusi Arabic: Alcalá (1883:329) renders Complines as al âyx̌̆, and Matins as al âáteme. 
While not a calque, the widespread Tuareg name of 'Ishā', aẓuzəg "milking", may be indirectly associated with this name. Some of the hadith cited as condemning the term 'atama explain its usage as the result of a Bedouin practice of praying it after milking the camels after nightfall, cf. Musnad Ahmad \#4688 (Ibn Hanbal 1995:315) (apparently a variant of the hadith from Muslim cited above):

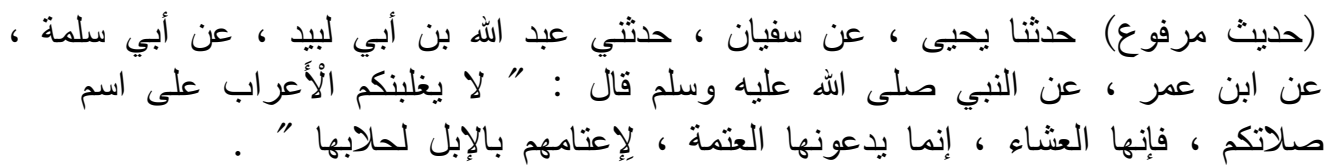

[...] From Ibn 'Umar, from the Prophet, blessings and peace be upon him, who said: "Let the Bedouins not prevail over you in the name of your prayer, for it is al- 'isha' ; they (the Bedouins) call it al- 'atama because they keep the camels out late to milk them."

\section{5. Ṣalät al-Nawm ('Ishā')}

This form, literally "prayer of sleep", is very marginal in the hadith literature, but its rarity in Arabic contrasts with the overwhelming frequency in Berber of its calque, $t i-n$-idos "that (f.) of sleep". This form is used in Tashelhiyt and Tamazight in southern Morocco; the Zenati Berber-speaking oases stretching across the northern Algerian Sahara, including the Gūrāra and Mzāāb; Western Libya, including Zuwāra, Ghadames, and Al-Fuqahā'; and Zenaga in Mauritania. It has been borrowed into Korandjé (Algeria), as tsyạdọs.

The same calque was made in Soninké, whether directly from Arabic or from Berber: sákhú-fó ("sleep-thing"). From Soninké this form was borrowed, with regular loss of $k h$ and compensatory vowel lengthening, into many other West African languages: Mandinka sáafu, Songhay saafoo, Pular saf'i, etc. The Songhay form is explained by Prost (1977:637), following a suggestion by Marty (1920:228) for Peul, as deriving from Arabic shafaq "twilight", but if that were the case we would expect a short vowel: *safoo rather than saafoo. Nor would this explain the vowels and the position of the $k h$ in the Soninké form. To make matters worse, 'Ishā' cannot be prayed until after shafaq has passed (Monnot 1995:960); shafaq is in fact the time of the Maghrib prayer. The Peul form cited by Marty, safako, clearly is based on shafaq, but given its meaning, it is better viewed as the result of a folk-etymological reinterpretation (among Arabic-literate scholars) of a term originally based on sákhú-fó. Marty (1920:70) links the Songhay form itself to shaf', the name of the optional prayer immediately following 'Ishā'; this fits the Pular form, but otherwise again fails to account for the long $a a$ and the other regional forms.

\section{6. Șalāt al-Ghadāt (Șubḥ)}

This form has already been exemplified above. Medieval eastern Berber used what I take to be a calque of ghadāt (properly "early morning"), folk-etymologised as based on ghad "tomorrow": ti-n-uzəčča "that (f.) of tomorrow". This term, however, has not survived into any reported modern variety. Some of the Tuareg forms are ambiguous between subh and ghadāt: tufat means both "morning" and "tomorrow", like Spanish mañana. Other Berber 
terms for the morning prayer show far more variation than the other four prayers; where they are not Arabic loans, they may be calques of subh "(early) morning" (Tamasheq, Zenaga, Sīwa), or just terms meaning "early" (Zuwāra, Nafūsa).

\section{7. Șalāt al-Ghabasha (Ṣubḥ)}

Within North Africa, borrowed reflexes of this form are reported only in the Berber languages of the Mzāāb and Ouargla, two of the last strongholds of Ibāḍism, and Awjila (Paradisi glosses it only as "morning", but Mauri (2011, ms) confirms the prayer time sense). No early authority for this form as a prayer name has yet been found, but it is in current use in colloquial Arabic in the other main region where Ibādism has been maintained, eastern Arabia. Examples from Oman in a highly colloquial register can readily be found online, eg:

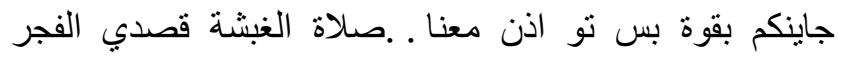

Coming in force but now the ad̄ān is with us.. the Ghubsha, I mean Fajr, prayer.

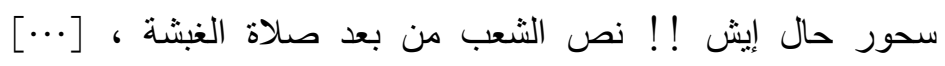

Suhūr like what!! Half the people after Ghubsha prayer, $[\ldots]^{4}$

While the name itself seems absent from the hadith literature, its motivation can readily be found there; cf. Mālik \#1.9 (1985:8):

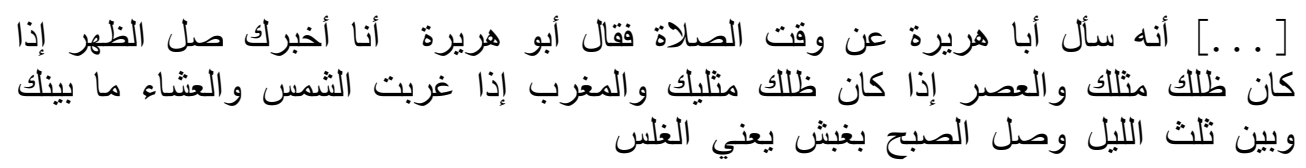

[...] he asked Abū Hurayra about the time of prayer. Abū Hurayra replied: "I will tell you. Pray Đuhr when your shadow is your size, and 'Așr when it is twice your size, and Maghrib when the sun sets, and 'Ishā' within the (first) third of the night, and pray Șubh in ghabash, meaning ghalas (just before daybreak)."

\section{Berber-internal innovations}

\subsection{Prayer names based on calling}

In several varieties spoken in or around southwestern Libya, Đuhr is called imaghri, a verbal noun from ghar "to call". The same term is found in a Tuareg variety further from Libya, Tamasheq, but with reference to Șubh. A probably independent development of the

3 http://www.s-oman.net/avb/showthread.php?t=570770\&page=7

4 http://www.omanlover.org/vb/showthread.php?t=169981\&page $=7$ 
same kind is Ayt Hdiddou tighuriwin, a feminine plural based on the same root, for Maghrib.

\subsection{Prayer names based on numerals}

While most Berber languages have borrowed most of their numerals from Arabic, several preserve the original system, as exemplified by the following table:

Table 2: Some numerals in Berber

\begin{tabular}{|l|l|l|l|l|}
\hline & & four & five & six \\
\hline Zenaga & (Taine-Cheikh 2008) & akkuź & shämmush & shuạish \\
\hline Tashelhịt & (Destaing 1920) & kkuz & smmus & sḍis \\
\hline Tamasheq & (Heath 2005) & ăkkoz & sămmos & saḍdis \\
\hline
\end{tabular}

As noted by van den Boogert and Kossmann (1997), these seem to provide the sources for some Berber prayer names. Throughout a wide area roughly coinciding with the distribution of ti-zwar(-nin) above - including Tashelhiyt and Tamazight in southern Morocco; the Zenati Berber-speaking oases stretching across the northern Algerian Sahara, including the Gūrāra and Mzāāb; Northwestern Libya, including the Nafūsa mountains and Zuwāra; Tuareg in the central Sahara; and Zenaga in Mauritania - 'așr is referred to as $t$ $a k k^{w} z$-in, a feminine plural based on $k k u z$ "four". Beyond Berber, this form has been borrowed from Zenaga into Wolof, as tàkkusaan, and Korandjé, as tsakwzżn.

In a rather smaller area, including most of the Zenati Berber-speaking oases of the northern Algerian Sahara, along with Nafūsa and Al-Fuqahā' in western Libya, the maghrib prayer is referred to as ti-səmms-in, a feminine plural based on sammus "five". The term is also attested with a vaguer meaning "afternoon" in Tamezret (southern Tunisia).

In many Tuareg varieties, the 'ish $\bar{a}$ ' prayer is $t i$-suds-en, an etymologically ambiguous feminine plural. Naït-Zerrad (1998) derives it from the causative verb sudəs "to make sleep" (Foucauld 1951), thus fitting it with the tin-idos forms seen above. However, van den Boogert and Kossmann (1997) note that a derivation from sadis "six" cannot be excluded. In light of the other two numerical forms, this derivation seems plausible.

Naiit-Zerrad (1998:63) explained the forms for 'Așr and Maghrib on the basis that the (24hour) day starts after sunset, making Maghrib the $5^{\text {th }}$ and last prayer within it. This view is reasonable in itself; such a definition of the day was commonplace in the Islamic world, and is supported by the Morisco Spanish form alajere "Maghrib" < al-'ākhira (cp. Alcalá's (1883:329) al akirǐ, given as "Nones" but probably transposed from "Vespers"). However, this does not sit well with the fact that, in all the languages which use these numerical forms, Đuhr is consistently named as "the first". If Maghrib is the fifth prayer, then Đuhr should be third; or, conversely, if speakers who view Đ̣uhr as "first" are naming prayers ordinally, we expect "Așr to be "second", and Maghrib "third". Moreover, we would have to dismiss the otherwise promising similarity between the Tuareg terms for "Ishā' and "six" as a coincidence: there is no sixth obligatory prayer! Nor are there three prayers between 
Đuhr and 'Așr. For an explanation to fit the numerical forms for Đ̣uhr, 'Așr, and Maghrib all at once, let alone 'Ishā', we must abandon the idea of ordinally named prayers.

Happily, an alternative solution is available. Let us take the numerals to represent, not an ordering of prayers, but rather the times of the prayers, as measured by some numerical time-keeping system. The average time between Đuhr and Maghrib is 6 hours; in fact, if we use seasonal rather than equinoctial hours, as medieval sources commonly do, the time between them is always six seasonal hours by definition. Thus, if the interval between Đuhr and Maghrib is $(5-1)=4$ units, the unit in question must equal (6 / 4) hours, ie 1 hour 30 minutes. The day would be made up of 8 such units, and the night of another 8 such units.

Such a unit is not a mere artefact of imaginative reconstruction; it is well-attested in Saharan Berber culture. In the desert, irrigation water is frequently too scarce to allow everyone unlimited use, and measurement by volume is rarely practical. Most Saharan oases instead handle water rights through time measurement: for any particular spring or canal, each owner has the right to irrigate from it for a specific time-span each day, determined contractually. In order to measure this time-span, they divide the day into a fixed number of units, just as modern society does. In Ouargla, Ghadames, and Sīwa, the day was divided into 8 units of 1 hour 30 minutes each, called ttman at Sīwa and Ouargla (< Arabic tumn "one-eighth"; Souag (2013:119) for Sīwa, Delheure (1988:196) for Ouargla), and anattam at Ghadames (< Berber, cp. tam "eight"; Lanfry (1973:273)).

This would yield, on average, the following times for prayers:

$\begin{array}{lll}1^{\text {st }} \text { anattam } & \text { Đuhr } & 12: 00 \text { (normalised; add or subtract depending on time zone) } \\ 2^{\text {nd }} \text { anattam } & - & 13: 30 \\ 3^{\text {rd }} \text { anattam } & - & 15: 00 \\ 4^{\text {th }} \text { anattam } & \text { 'Așr } & 16: 30 \\ 5^{\text {th }} \text { anattam } & \text { Maghrib } & 18: 00 \\ 6^{\text {th }} \text { anattam } & \text { 'Ishā' } & 19: 30\end{array}$

The time given here for "Așr will strike most modern North Africans as a little too late. Contrast the actual spring equinox times for Ghadames as calculated by IslamicFinder.org ${ }^{5}$, subtracting 30 minutes to normalise for the time zone:

$\begin{array}{ll}\text { Đuhr } & 12: 00 \\ \text { 'Așr } & 15: 27 \\ \text { Maghrib } & 18: 05 \\ \text { 'Ishā' } & 19: 22\end{array}$

5

http://www.islamicfinder.org/prayerPrintable.php?city2=Ghadames\&state $=\& i d=11837 \&$ longi $=9.5000 \&$ lat $\mathrm{i}=30.1333 \&$ country $2=$ Libya\&zipcode=\&today_date_flag=2013-3-

$23 \&$ changeTime $=16 \&$ pmethod $=2 \&$ HanfiShafi $=1 \&$ DhuhrInterval $=1 \&$ MaghribInterval $=1 \&$ dayLight $=0 \& d$ ayl $=0 \&$ time $=2 \&$ dayLight_self_change $=\&$ prayerCustomize $=1 \& l a n g=\&$ fajrTwilight $=0 \&$ ishaTwilight $=0 \& \mathrm{i}$ shaInterval $=0 \&$ month $=3 \&$ year $=2013$ 
According to this calculation, Maghrib and 'Ishā' are correct to within less than 10 minutes. However, 'Așr comes out off by an hour. This, however, can easily be remedied. 'Așr has not one recognised time, but two: while most schools prefer to pray it when the shadow of an object is longer than at noon by the same length as its height, the Hanafi school instead prays it when it is longer by twice its height, and both alternatives are supported by hadith (King 1990). If we change the calculation method to Hanafi on the same site, and again subtract 30 minutes, then we get the following:

$\begin{array}{ll}\text { Đuhr } & 12: 00 \\ \text { 'Așr } & 16: 22 \\ \text { Maghrib } & 18: 05 \\ \text { 'Ishā' } & 19: 22\end{array}$

On the simple assumption that the twice-height method was followed, the anomaly thus disappears, and the implied timing is almost exactly correct.

Archeological investigations of Garamantian settlements have made it clear that irrigationbased oasis agriculture was already practiced by the Berbers of central Libya centuries before Islam (Wilson 2005). Such irrigation is hardly practicable without some means of dividing up time in order to divide water appropriately. It is therefore probable that, at the arrival of Islam, the settled Berbers of the Sahara and its fringes already had a time-telling system corresponding to the anattam of Ghadames and the ttmon of Siwa and Ouargla. They adopted noon as "the first" based on the prayer's alternative Arabic name, and named the following prayers based on the number of anattams elapsed counting from noon.

\section{Conclusion}

Saharan and Moroccan Berber, Soninké, and Songhay have all preserved, and transmitted to their neighbours, traces of Islamic religious terminology found in the hadith literature but largely obliterated elsewhere by pressures towards standardisation which can already be seen in that very literature. Indeed, Siwi Berber preserves the variant system labelled "Basran" above almost in its entirety. The terminology al-'ūlā for Đuhr and al-nawm / al'atama for 'Ishā' must have been dominant among the Muslims that reached the region in the Umayyad period. These variants' distribution correlates well with the fact that, at the time when what would come to be accepted as the key hadith collections and Sunni madhhabs were emerging, the trans-Saharan trade was largely in the hands of Muslims who did not accept the political authority of the Abbasid empire or the religious authority of its scholars. In addition to calquing Arabic terminology, Berber also coined new terms based on pre-existing Berber time-keeping systems, whose relative antiquity this fact confirms. 


\section{Data: Names of prayer times in languages of the Western Islamic world}

Tables 3 and 4 summarize the data used in this paper. A few Berber languages also have attested native terms for tarawih the long supererogatory prayers of Ramadan: Ouargla tizgrarin, Zenaga təžzgrärən. The etymology is transparent in both cases, being the feminine plural of the Berber adjective "long" in Ouargla (though Zenaga uses a different root for the adjective).

Table 3: Variant prayer names in Berber.

\begin{tabular}{|c|c|c|c|c|c|c|}
\hline & & Șubḥ & Đ̣uhr & 'Așr & Maghrib & 'Ishā' \\
\hline Zenaga & (Taine-Cheikh 2008) & $t(\ddot{a}) n \ddot{a} z z \ddot{a} T$ & tožbaran & takkūźż & tnut ${ }^{y} \operatorname{sha} ?^{2}$ & təN $N^{y} u ̛ ̣ a s h s h ə n$ \\
\hline \multicolumn{7}{|l|}{ Moroccan Atlas: } \\
\hline Old Tashelhiyt & $\begin{array}{l}\text { (Ibn Tūnirt, via Boogert \& } \\
\text { Kossmann 1997) }\end{array}$ & & tizwarn & takkzin & tiwwutshi & tiyyits \\
\hline Tashelhịt & (Destaing 1920) & (șşbah) & tizwaran & $t^{\prime a} k^{w} z i n$ & tiwutsh & tiyidəos \\
\hline $\begin{array}{l}\text { Ait Hdiddou } \\
\text { Tamazight }\end{array}$ & (Azdoud 2011) & $\begin{array}{l}(\text { lafžzr }) \\
(\text { ș̣ubḥ) }\end{array}$ & tizwarrin, (dduhr) & (l'aṣr) & $\begin{array}{l}\text { tighuriwin, } \\
\text { (lmaghrab) }\end{array}$ & tin yitț, (l'isha) \\
\hline Ait Atta Tamazight & (Amaniss 1980) & & tizwarnin & & tin-wittshi & tin-yiț \\
\hline $\begin{array}{l}\text { Ait Khebbach } \\
\text { Tamazight }\end{array}$ & (author's field data) & $(s b a h)$ & tizwarnin, tuzwarin & (l'așoṛ) & $\begin{array}{l}\text { tinwuččin, } \\
\text { tawučči }\end{array}$ & tinyaț \\
\hline \multicolumn{7}{|l|}{ Tuareg: } \\
\hline Tamasheq & (Heath 2006) & tífawt, emăghărr & tézzar & tákkaṣt & álməz & tisódsen \\
\hline Ahaggar Tamahaq & (Foucauld 1951:1157) & tufat & tezzar, emaghri & takkast & alməz & aẓuz̧oǵ, tisuțsin \\
\hline Ghāṭ Tamahaq & (Nehlil 1909:193) & tufat & imaghri & takost & alməz & tadəğğat \\
\hline Taitoq Tamajeq & (Masqueray 1893:266) & tufat & tizzar & takkost & alomoz & azozožğ \\
\hline
\end{tabular}




\begin{tabular}{|c|c|c|c|c|c|c|}
\hline & & Șubh & Đ̣uhr & 'Așr & Maghrib & 'Ishā' \\
\hline \multicolumn{7}{|l|}{ Zenati: } \\
\hline Figuig & (Sahli 2008, Kossmann p.c.) & lafžar & tizzarnin & l'așar & lmaghrab & tinyit \\
\hline Igli & $\begin{array}{l}\text { http://www.igli08.com/vb/sh } \\
\text { owthread.php?t=941 }\end{array}$ & & tizarnin & (l'așr) & tisəmsin & tiniț \\
\hline Timimoun & (Boudot-Lamotte 1964) & & tizza'nin & takzin & tisəmsin & tinnist \\
\hline Ouargla & (Delheure 1987) & (ghabəshsha) & tazzarnin & $\operatorname{takk}^{w}$ zin & tisəmməsin & tinniḍos \\
\hline Mzāāb & $\begin{array}{l}\text { (Brahim Abdessalam \& Bekir } \\
\text { Abdessalam 1996:47) }\end{array}$ & (ghboshsha) & tizzarnin & $t^{2} k^{w}$ in & tisəmsin & tinniḍdas \\
\hline \multicolumn{7}{|l|}{ "Eastern": } \\
\hline Tamezret & (Ben Mamou 2005) & & & & $\begin{array}{l}\text { tisamsin } \\
\text { "après-midi" }\end{array}$ & \\
\hline Zuwāra & (Mitchell 2009:327-327) & talži & tizzarnin & tuqzin & timutshu & tiniḍas \\
\hline Nafūsa & $\begin{array}{l}\text { (Calassanti-Motylinski } \\
\text { 1898:36) }\end{array}$ & afallah $n$ taji & tizarnin & tuqzin & tisamsin & tinmonsi \\
\hline Old Eastern Berber & $\begin{array}{l}\text { (Calassanti-Motylinski } \\
\text { 1898:36) }\end{array}$ & tinuzəčča & tizarnin & tuqzin & tinučču & tinidas \\
\hline Sawkna & (Sarnelli 1924:21) & & imaghri & & & \\
\hline Al-Fuqahā' & (Paradisi 1963:118) & (alfážar) & mghári & (al'áṣar) & tsamsín & tniațást \\
\hline Ghadames & (Lanfry 1973:194) & (așṣāla) / maddēn & ama'ri & (ăl'așər) & аßәппљßәп & tanēdas \\
\hline Awjila & $\begin{array}{l}\text { (Paradisi 1960; Paradisi } \\
\text { 1961) }\end{array}$ & $\begin{array}{l}\text { (alghábəsh } \\
\text { "mattino presto") }\end{array}$ & (alúli) & (l'áșar) & mnishiw & \\
\hline Sīwa & (author's field data) & tənnaddan / sra & (luli) & (la șarar) & (mmaghrab) & (l'atmat) \\
\hline
\end{tabular}


Table 4: Variant prayer names in non-Berber languages.

\begin{tabular}{|c|c|c|c|c|c|c|}
\hline & & Șubh & Đ̣uhr & 'Asṣr & Maghrib & 'Ishā' \\
\hline $\begin{array}{l}\text { Morisco Spanish } \\
\left(16^{\text {th }} \text { cent. }\right)\end{array}$ & $\begin{array}{l}\text { (Dadson 2012; Gredilla } \\
\text { 1874) }\end{array}$ & $\begin{array}{l}\text { (alcobh, } \\
\text { cofe) }\end{array}$ & (doar, dohar) & (hazar, alaçare) & (elegin, alajere) & (hatamay, alatamo) \\
\hline Wolof & (Diouf 2003) & njël, (fajar) & tisbar & tàkkusaan & timis & geewe \\
\hline Korandjé & (author's field data) & (l)mandar & tazbạrṛan & $t s a k^{w} z z \partial n$ & tsyunəs & tsyạdạs \\
\hline Gao Songhay & (Heath 1998) & (subbaahi) & (aluula) & (alaasar) & (almaari) & assaafoo \\
\hline $\begin{array}{l}\text { Timbuktu } \\
\text { Songhay }\end{array}$ & (Heath 1998) & (alfajar) & (aluula) & (alaasara) & (fitirow, futurow, fitrow) & assaafoo, saafoo \\
\hline Soninké & (Diagana 2011) & (fájìrí) & $\begin{array}{l}\text { sállì-fànà } \\
\text { ("prayer-first") }\end{array}$ & (làxáasàrá) & (fütúrò) & $\begin{array}{l}\text { sákhú-fó } \\
\text { (“sleep-thing") }\end{array}$ \\
\hline Bozo of Mopti & $\begin{array}{l}\text { (Daget, Konipo \& } \\
\text { Sanankoua 1953) }\end{array}$ & $\begin{array}{l}\text { (alfadyiri, } \\
\text { fadyiri) }\end{array}$ & salifana & & & saà pó (“sleep thing”) \\
\hline Mandinka & (Creissels 2011) & (súbaa) & sálífanaa & (alánsara) & (fitiri) & sáafu \\
\hline Bambara & (Bailleul 1981) & & selifàna & (làansàra) & (fitiri) & saafo \\
\hline Futa Jalon Pular & (Bah 2012) & subaka & fanaa & alansaraa & futuroo & saf'i, geeye \\
\hline Macina Peul & (Marty 1920:228) & fadyiri & sallifana & lassara & fitiri & safako, guédié \\
\hline
\end{tabular}




\section{References}

Abdessalam, Brahim \& Bekir Abdessalam. 1996. al-Wajīz fì Qawā 'id al-Kitāba wa-n-Nahww li-l-Lugha al-'Amāzīghiyya "al-Mzābiyya” - al-Juz' al-'Awwal. Ghardaia: alMațba'a al-'Arabiyya.

Amaniss, Ali. 1980. Dictionnaire tamazight-français (parlers du Maroc centrale). http://www.amazighworld.org/uploadedfiles/dictionnaire_Francais_Tamazight.pdf.

Arnold, Werner. 1990. Das Neuwestaramäische. (Semitica Viva 4). Wiesbaden: Harrossowitz.

Azdoud, Driss. 2011. Dictionnaire berbère-français. Paris: Maison des sciences de l'homme.

Bah, Oumar. 2012. Saggitorde. Peeral.com. http://peeral.com/saggitorde/abstract/main.htm.

Bailleul, Charles. 1981. Petit dictionnaire bambara-français, français-bambara. Amersham: Avebury.

Boogert, Nico van den \& Maarten Kossmann. 1997. Les premiers emprunts arabes en berbère. Arabica: Journal of Arabic and Islamic Studies 44. 317-322.

Boudot-Lamotte, Antoine. 1964. Notes ethnographiques et linguistiques sur le parler berbère de Timimoun. Journal Asiatique CCLII. 487-558.

Bukhārī, 'Abū 'Abd Allāh Muḥammad ibn 'Ismā'īl al-. 2001. Al-Jāmi' al-Ṣaḥịh. (Ed.) Muhammad Zuhayr ibn Nāṣir al-Nāșir. Beirut: Dār Ṭawq al-Najāt.

Calassanti-Motylinski, A. de. 1898. Le Djebel Nefousa: Transcriptions, traductions et notes, avec une étude grammaticale. Paris: Ernest Leroux.

Creissels, Denis. 2011. Lexique mandinka-français (état provisoire, mars 2011). http://deniscreissels.fr.

Dadson, Trevor J. 2012. The Moriscos of Villarrubia de los Ojos. In Kevin Ingram (ed.), The Conversos and Moriscos in Late Medieval Spain and Beyond. Volume Two: The Morisco Issue. Leiden: Brill.

Daget, J., M. Konipo \& M. Sanankoua. 1953. La langue bozo. Bamako: IFAN.

Delheure, Jean. 1987. Agerraw $n$ iwalen teggargrent-tarumit $=$ Dictionnaire ouarglifrançais. (Études Ethno-linguistiques Maghreb-Sahara 5). Paris: Société d'Etudes Linguistiques et Anthropologiques de France.

Delheure, Jean. 1988. Vivre et mourir à Ouargla = Tameddurt t-tmettant Wargren. (Etudes Ethno-linguistiques Maghreb-Sahara 7). Paris: Société d'Etudes Linguistiques et Anthropologiques de France.

Destaing, Edmond. 1920. Etude sur la Tachelhît du Sous. Vol. I: Vocabulaire françaisberbère. Paris: Ernest Leroux.

Diagana, Ousmane Moussa. 2011. Dictionnaire soninké-français (Mauritanie). Paris: Karthala.

Diouf, Jean Léopold. 2003. Dictionnaire wolof-français et français-wolof. (Dictionnaires et Langues). Paris: Karthala.

Foucauld, Charles Eugène de. 1951. Dictionnaire touareg-français: dialecte de l'Ahaggar. Paris: Imprimerie Nationale de France.

Gredilla, G. P. 1874. Ceremonias de Moros que hacen los Moriscos. Revista de archivos, bibliotecas y museos IV. 165-169.

Harrell, Richard S. \& Harvey Sobelman. 2004. A Dictionary of Moroccan Arabic: Moroccan-English/English-Moroccan. Georgetown: Georgetown University Press.

Heath, Jeffrey. 1998. Dictionnaire songhay-anglais-français. (Langues d'Afrique 4-6). Paris: L'Harmattan. 
Heath, Jeffrey. 2005. A Grammar of Tamashek (Tuareg of Mali). (Mouton Grammar Library 35). Berlin: Mouton de Gruyter.

Heath, Jeffrey. 2006. Dictionnaire touareg du Mali: tamachek-anglais-français. Paris: Karthala.

Ibn 'Ab̄̄ Shayba, Abū Bakr 'Abd Allāh ibn Muhammad. 2006. Al-Muṣannaf. (Ed.) Muhammad 'Awwāma. Vol. 19. Beirut: Dār Qurțuba.

Ibn Hanbal, Aḥmad. 1995. Musnad Al-'Imām 'Aḥmad ibn Hanbal. (Ed.) Shu'ayb alArna'ūt \& 'Ādil Murshid. Vol. 8. Beirut: Al-Resalah.

King, David A. 1990. Mīkāt: Astronomical timekeeping. Encyclopaedia of Islam. Leiden: Brill.

Lanfry, Jacques. 1973. Ghadamès II: Glossaire (parler des Ayt Waziten). Fort-National (Algérie): Le Fichier Périodique.

Mālik ibn 'Anas. 1985. Al-Muwațta'. Beirut: Dār 'Ihyā' al-Turāth al-'Arabī.

Ben Mamou, Larbi. 2005. Dialecte berbère de Tamezret (Tunisie). Atmazret. http://atmazret.info/ (3 November, 2006).

Marty, Paul. 1920. Etudes sur l'Islam et les tribus du Soudan. Tome II : La région de Tombouctou (Islam songaï); Djenné, le Macina et dépendances (Islam peul). Paris: Ernest Leroux.

Masqueray, Emile. 1893. Dictionnaire français-touareg (dialecte des Tä̈toq). Paris: Ernest Leroux.

Mauri, Simone. 2011 (ms). A few notes on the moribund Berber dialect of Awjilah (eastern Libya).

Mitchell, Terence F. 2009. Zuaran Berber (Libya): Grammar and Texts. (Ed.) Harry Stroomer \& Stanly Oomen. (Berber Studies v. 26). Köln: Rüdiger Köppe.

Monnot, G. 1995. Șalāt. Encyclopédie de l'Islam. Leiden: Brill.

Mubarrad, Abū al-'Abbās Muḥammad Al-. 1864. The Kāmil of El-Mubarrad. (Ed.) William Wright. Leipzig: Kreysing.

Muslim ibn Hajjāj. 2006. Șaḥịh Muslim. (Ed.) Abū Qutayba Nađ̛̣ar Muhammad al-Fāryābī. Riyadh: Dār Tīiba.

Naït-Zerrad, Kamal. 1998. Lexique religieux berbère et néologie: un essai de traduction partielle du coran. Milan: Centro Studi Camito-Semitici.

Nehlil. 1909. Étude sur le dialecte de Ghat. Paris: Ernest Leroux.

Paradisi, Umberto. 1960. Il berbero di Augila, Materiale lessicale. Rivista degli Studi Orientali XXXV.

Paradisi, Umberto. 1961. Testi berberi di Augila (Cirenaica). Annali Istit. Univers. Orient. Napoli X. 79-91.

Paradisi, Umberto. 1963. Il linguaggio berbero di El-Fógăha (Fezzân). Istituto Orientale di Napoli XIII. 93-126.

Pedro de Alcala, Paul de Lagarde. 1883. Petri Hispani De lingua arabica libri duo. Otto Zeller. http://archive.org/details/petrihispanidel00lagagoog (28 March, 2013).

Prost, A. 1977. Supplement au dictionnaire Sonay-Francais (parler de Gao, Mali). Bulletin de l'Institut Fondamental d'Afrique Noire. Série B: Sciences Humaines Dakar 34. 584-657.

Qurțub̄ị, 'Abū 'Abd Allāh Muḥammad ibn 'Aḥmad ibn 'Abī Bakr. 2006. Al-Jāmi' li'Ahkām al-Qur'ān. (Ed.) 'Abd Allāh ibn 'Abd al-Muḥsin al-Turkī. Vol. 11. Beirut: Al-Resalah.

Sahli, Ali. 2008. Mu 'jam Amāzīghì- 'Arabī (khāṣs bi-lahjat 'ahālī Fijīj) yadummu qawā 'id hādhihi l-lahja wa-jāniban min turāthihā l-'adabì. Oujda: El Anouar El Maghribia. 
Șan'ānī, Abū Bakr 'Abd al-Razzāq ibn Hammām. 1970. Al-Muṣannaf. (Ed.) Habīb alRaḥmān 'A'đ̛̣amī. Beirut: Al-Majlis al-'Ilmī.

Sarnelli, Tommaso. 1924. Il dialetto berbero di Sokna: Materiali lessicali, testi manoscritti in caratteri arabi, con trascrizione e traduzione. Supplemento all'Africa Italiana.

Souag, Lameen. 2013. Berber and Arabic in Siwa (Egypt): A Study in Linguistic Contact. (Berber Studies 37). Köln: Rüdiger Köppe.

Taine-Cheikh, Catherine. 2008. Dictionnaire zenaga-francais: le berbere de Mauritanie présenté par racines dans une perspective comparative. (Berber Studies v. 20). Köln: Rüdiger Köppe.

Wensinck, A. J. 1987. Mīkāt. First Encyclopaedia of Islam. Leiden: Brill.

Wilson, Andrew. 2005. Foggara irrigation, early state formation and Saharan trade: the Garamantes of Fazzan. Schriftenreihe der Frontinus-Gesellschaft 26. 223-234.

Woidich, Manfred \& Peter Behnstedt. 1982. Die ägyptische Oasen - ein dialektologischer Vorbericht. Zeitschrift für arabische Linguistik 8. 39-71. 